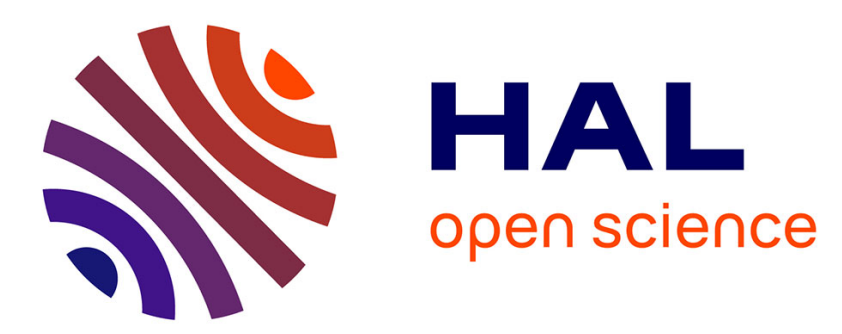

\title{
Facing Creation: When the Pragmatic Credo Masks the Orders of Action
}

\author{
Mathias Béjean, Armand Hatchuel
}

\section{To cite this version:}

Mathias Béjean, Armand Hatchuel. Facing Creation: When the Pragmatic Credo Masks the Orders of Action. Philosophy of management, 2017, 16 (3), pp.1-14. 10.1007/s40926-017-0062-1 . hal01547025

HAL Id: hal-01547025

https://hal-mines-paristech.archives-ouvertes.fr/hal-01547025

Submitted on 26 Jun 2017

HAL is a multi-disciplinary open access archive for the deposit and dissemination of scientific research documents, whether they are published or not. The documents may come from teaching and research institutions in France or abroad, or from public or private research centers.
L'archive ouverte pluridisciplinaire HAL, est destinée au dépôt et à la diffusion de documents scientifiques de niveau recherche, publiés ou non, émanant des établissements d'enseignement et de recherche français ou étrangers, des laboratoires publics ou privés. 


\title{
Facing Creation: When the Pragmatic Credo Masks the Orders of Action
}

Mathias Béjean ${ }^{1}$, Armand Hatchuel ${ }^{2}$

\section{TO CITE THIS ARTICLE /}

Béjean, M. \& Hatchuel, A. Philosophy of Management (2017). doi:10.1007/s40926-017-0062-1

\section{Mathias Béjean}

mathias.bejean@u-pec.fr

\author{
Armand Hatchuel \\ armand.hatchuel@mines-paristech.fr
}

\begin{abstract}
This paper discusses the problematic use of the "pragmatic credo" - defined as a minimal set of basic pragmatist propositions - in practice, especially when facing creation. To do so, we analyze how managers deal with "art-based firms" and provide results from an in-depth case study of a small firm operating in garden art and design (Béjean 2015; Béjean 2008). The findings are interpreted in light of previous theoretical developments in management theory (Hatchuel 2005), as well as symbol theory (Goodman 1968; Goodman 1978). They suggest that, while appearing wise and reasonable, the pragmatic credo as embodied in practical management doctrines rather inhibits collective action and masks the necessary revision of symbolic "orders of action", defined as the way action is itself precategorized by a special class of symbols. The paper concludes by providing further insights of how an "epistemology of action" could contribute to enriching both pragmatism and management, especially when action is no longer the solution to resort to but rather the enigma to unfold.
\end{abstract}

Keywords Please provide 4 to 6 keywords which can be used for indexing purposes.

\footnotetext{
${ }^{1}$ Associate Professor at Université Paris Est Créteil

${ }^{2}$ Professor at Mines ParisTech / PSL Research University
} 
Pragmatism; philosophy of management; meaning-making; symbolic functioning; epistemology of action; orders of action. 


\section{Introduction}

"Nature shows no action" - John William Miller

\section{Why discussing the "pragmatic credo" when facing creation?}

This special issue deals with the links between "pragmatism" and "innovation" and one important question is: "can one be pragmatic if one produces the unknown?" Of course, since pragmatists have often presented their philosophy as a privileged path towards freeing human beings from any old form of "dogmatism" - e.g. rationalism, idealism -, they would certainly be surprised by the question itself and even argue further that pragmatism has precisely consisted in conceiving human action as fundamentally "creative" (Joas 1996). Still, it seems that the current issue rather calls attention to the problematic use of the "pragmatic credo" - defined as a minimal set of basic pragmatist propositions - in practice, especially when facing creation. In line with such questioning, the aim of this paper is therefore not to discuss the pragmatist philosophy itself, but rather to analyze a specific "embodiment" of the pragmatic credo in practice, assess its contribution and limitations when facing creation, and finally come back to pragmatism with new questions. To do so, we suggest analyzing how managers deal with creation in the particular case of "art-based firms."

\section{Why studying management?}

Generally speaking, "management" refers to a quite recent and heterogeneous scientific corpus in which, like in the case of pragmatism, "action" has been a central issue. In this paper, we will not discuss academic theories of management, but focus on "popular management", defined as the mainstream doctrine which was formed during 1900 and 1940 and which spread internationally after World War II. This doctrine is still nowadays an important reference for practitioners and is currently taught in many business schools or MBA around the world. It is often named "business administration", in reference to French (Fayol 1916) and North American (Gulick 1937; Gulick and Urwick 1937) original scientific developments in management theory ${ }^{3}$. We argue that this managerial doctrine is a close embodiment of the pragmatic credo and that it could therefore be an interesting "study model" for discussing pragmatism in practice. In the following, the terms "managerial" or "management", if not specified, will by default refer to this doctrine.

3 Even if Fayol's work is now viewed as much more complex than popular business administration 


\section{Why confronting management with art?}

Our assumption is that the artistic contexts are an "extreme case" (Yin 2003) which challenge traditional views of management. There have already been numerous attempts to discuss conventional tenets of management further and find new ways in which to apply or teach them in the case of artistic contexts. Likewise, many of the recent theoretical approaches to management and organizations have drawn on art and aesthetics to enrich traditional representations (e.g. Strati 1992; Guillet de Monthoux 2004; Taylor and Hansen 2005; Riot and Bazin 2013; Barry and Hansen 2008). In line with such critical approaches, we build on findings from a single longitudinal case study of a small firm operating in garden art and design. We argue that symbolic processes at work in art raise new organizational issues which cannot be understood only with the pragmatic credo as a mindset.

The paper is organized as follows: in a first section we clarify our understanding of the "pragmatic credo" and justify the use of management as a "study model" for discussing it. Then, in a second and a third sections, we introduce and develop the case of Hamadryade. The findings are discussed in a fourth section in which we suggest revising three main assumptions of a pragmatic approach to management. In a fifth and final section, we conclude by providing insights of an "epistemology of action."

\section{Management as a "study model" for discussing pragmatism}

In this section, we use the term "study model" in reference to a method used in biosciences. In these contexts, it makes it possible to analyze an "embodiment" of a general phenomenon in a situation in which it can be more easily confined by the researcher. In these cases, after justifying the correspondence between the two phenomena - the one analyzed on the "study model" and the more general one the researcher can transfer the knowledge gained from the former to the latter. In our case, as the task of delineating the characteristics of "pragmatism" in general, if possible (e.g. Lovejoy 1908), was too ambitious for this paper, we decided to study a more confined phenomenon. In that sense, we determined to provide a restricted definition of what we consider to be the "pragmatic credo." Then, asserting that management sufficiently embodies this pragmatic credo in practice, we suggested using it as a "study model" for discussing pragmatism.

\section{Pragmatism(s): defining the "pragmatic credo"}

It is widely admitted that the term "pragmatism" refers to the major American philosophy which was founded in the late 19th century by Charles Sanders Peirce and then mainly developed through the seminal works of William James and John Dewey. It is also commonly recognized that "pragmatism" consists in the philosophy of considering practical consequences or effects of action to be fundamental elements of meaning and truth. 
Nonetheless, although this seminal and historical reference has shaped a common understanding of what "pragmatism" may widely encompass, it remains difficult to synthesize the heterogeneous developments of the "pragmatic movement." Three main reasons may be invoked to account for this difficulty. The first reason evidently lies in the fact that pragmatism has been and remains, a continuously evolving philosophy. This development has naturally led to different interpretations, reformulations and various versions of pragmatism. The second reason is that there are several bones of contention among the pragmatist authors themselves. For instance, Putnam was partly opposed to pragmatists such as James or Schiller who were rather inclined to consider truth as "mutable" (Putnam 1981). One of the consequences of these theoretical divergences is that sometimes there exists no consensus on deciding whether an author is really in line with the pragmatic credo or not. For example, Susan Haack was very critical about Richard Rorty's understanding of pragmatism, which she called "vulgar pragmatism" (Haack 1995). Finally, one may argue that another stumbling block towards defining "pragmatism" lies in the fact that many pragmatist authors have precisely developed against general "theories" and intellectualism. As result, there are rather "pragmatism-s" than "pragmatism."

For these reasons, it is necessary to clarify a "point of view" on pragmatism. In order to hone our own understanding, we selected a minimal set of basic pragmatist propositions, as summarized by Table 1. This limited set of propositions does not pretend to be exhaustive, but aims at sketching out our own vision of the "pragmatic credo" and constituting a basis for the current discussion.

Table 1 - Defining the "pragmatic credo"

\begin{tabular}{|c|c|c|}
\hline Truth, language, meaning & Moral and Ethics & Politics and Society \\
\hline $\begin{array}{l}\text { Pragmatism is a philosophy } \\
\text { which considers truth as } \\
\text { relativistic, constructed in } \\
\text { practice and, above all, } \\
\text { derived from experience } \\
\text { (e.g.: James' radical } \\
\text { empiricism (1912)). }\end{array}$ & $\begin{array}{l}\text { Pragmatists reject any } \\
\text { ontological distinction } \\
\text { between facts and values } \\
\text { (e.g.: Putnam's argument } \\
\text { on the fact-value } \\
\text { dichotomy (2004)). } \\
\text { They insist on the fact that } \\
\text { moral and ethical } \\
\text { statements could only }\end{array}$ & $\begin{array}{l}\text { Pragmatists above all } \\
\text { consider human beings as } \\
\text { "social beings" and } \\
\text { emphasize the notion of } \\
\text { "community", which plays a } \\
\text { constitutive role in the } \\
\text { establishing of an "ideal" } \\
\text { society (e.g.: Dewey's } \\
\text { democracy (1916)). }\end{array}$ \\
\hline
\end{tabular}




\begin{tabular}{|l|l|l|}
\hline $\begin{array}{l}\text { in itself, but rather that } \\
\text { meaning and truth }{ }^{4} \text { reside in } \\
\text { "beliefs" which have } \\
\text { proven "useful" in practice } \\
\text { and which "satisfy" us as } \\
\text { such (e.g.: Peirce's maxim } \\
(1877 ; 1878 ; 1958)) .\end{array}$ & $\begin{array}{l}\text { make sense in context or } \\
\text { "situation." }\end{array}$ & $\begin{array}{l}\text { Such a view stresses the } \\
\text { necessity of "consensus } \\
\text { building" and "participative } \\
\text { pragmatists believe that it } \\
\text { is possible to educate } \\
\text { liberalism (1991)). }\end{array}$ \\
& $\begin{array}{l}\text { people to such a moral } \\
\text { casuistic (e.g.: Dewey's } \\
\text { situated ethics (1969- } \\
1975))\end{array}$ & \\
& & \\
\end{tabular}

\section{Why using management as a "study model" for discussing pragmatism?}

Firstly, the etymology of the term "pragmatism" is interesting for our discussion. "Pragmatism" was actually a neologism created by Peirce on the basis of ancient Greek pragmata. This term was originally used to characterize a specific type of action in the particular context of "human affairs" and was mostly related to "business" or "politics." Several other notions, which have of course different connotations, could have either been selected, such as praxis (practical action) or poiésis (productive action). The etymological root, because obviously not chosen by chance by Peirce, thus calls attention to proximities in the way of conceiving action both in management and pragmatism. Moreover, regarding the current use of the word pragmatism, there are today a lot of references to the pragmatic credo in contemporary managerial discourses. These references manifest themselves either as "calls for" or "critics towards" pragmatism. In an issue of American newspaper The New York Times, Harvard Business School's professor Rakesh Khurana even declared: "If there is an ideology of management, it is pragmatism" (NYT, April, 11th 2009). Without "proving" anything, both the etymology and the common uses of the word "pragmatism" constitute converging signs which suggest an empirical proximity between both managerial and pragmatic doctrines of action.

From an analytical perspective, management like pragmatism combines the legacy of science and experimentalism with the social focus on "conduct principles" such as "authority" or "empowerment." In addition, the administrative doctrine is generally used as a reference for efficiency or performance when

${ }_{4}$ We are of course aware that truth and meaning are not strictly overlapping notions. Still, for the sake of clarity we determined to simplify this point. 
dealing with collective action and seems to be a close embodiment of the pragmatic credo as shown by Table 2 :

Table 2 Business administration as a close embodiment of the pragmatic credo

\begin{tabular}{|c|c|c|}
\hline Truth, language, meaning & Moral and Ethics & Politics and Society \\
\hline $\begin{array}{l}\text { Business administration } \\
\text { usually considers that } \\
\text { action can be observed } \\
\text { through objective } \\
\text { "indicators" of } \\
\text { effectiveness and } \\
\text { performance. As in the } \\
\text { case of pragmatism, this } \\
\text { scientific logic is supposed } \\
\text { to be a good way to capture } \\
\text { "effects of action." } \\
\text { For example, the "market } \\
\text { voice", which is a widely } \\
\text { used metaphor referring to } \\
\text { clients preferences, } \\
\text { validates the "right" } \\
\text { decisions of the firm and is } \\
\text { a sign of "reality" or } \\
\text { "satisfaction" used by } \\
\text { managers. }\end{array}$ & $\begin{array}{l}\text { Espousing pragmatic } \\
\text { values, business } \\
\text { administration generally } \\
\text { emphasizes the objective } \\
\text { social consequences of } \\
\text { individual actions when } \\
\text { dealing with ethical issues. } \\
\text { Researchers working in the } \\
\text { field of "business ethics" } \\
\text { therefore constantly argue } \\
\text { against rigid ethical codes } \\
\text { and rather praise the virtue } \\
\text { of context apprehension and } \\
\text { local experimentation. }\end{array}$ & $\begin{array}{l}\text { While emphasizing the } \\
\text { importance of "team" } \\
\text { leading and "cultural } \\
\text { identity", it also pays } \\
\text { much attention to issues } \\
\text { such as consensus } \\
\text { building, participation and } \\
\text { empowerment. }\end{array}$ \\
\hline
\end{tabular}

According to us, it is thus possible to establish a connection between the pragmatic credo and the tenets of business administration as outlined above. The question is then now: does the pragmatic credo, as embodied in business administration, provide an adequate theory of collective action when facing creation? To answer to that question, we will now use the case of art-based firms.

\section{Management facing creation: the case of art-based firms}

We define "art-based firms" as firms, the growth of which is committed to artistic development. This notion is stricter than the wide notion of "cultural 
industries" established in cultural economics (Hirsch 2000). Likewise, it differs from the paradigm of "small creative firms" (Bilton 2006) which rather applies to any kind of activities that have their origin in individual creativity. Our notion is closer to the notion of "art firms" developed by Pierre Guillet de Monthoux (2004) and focuses on artistic symbolic processes. We start with clarifying the analytical framework which was used to analyze the case. Then we precise the research settings and provide some general elements about the case study.

\section{Analyzing art-based firms: a focus on symbolic processes}

In line with previous research (Sicca 2000; Guillet de Monthoux 2004), we acknowledge the fundamental role of "signification" in art-related contexts and thus emphasized the symbolic processes underlying the creation of artistic value. To do so, we used Nelson Goodman's "worldmaking" as a guiding approach to the encounter of art and management (Béjean 2015). In his seminal books, Languages of art (Goodman 1968) and Ways of Worldmaking (Goodman 1978), Goodman developed an analytical framework to explain not "What is art?" but "When is art." Defining a "language" as a symbolic system which links a set of symbols with a domain of things (objects or other symbols) through different "referential functions" (e.g. denotation, expression, exemplification...), Goodman was more interested in describing symbolic functioning in art, than in understanding the unfathomable nature of the aesthetic experience. In other words, Goodman was convinced that, to exist as such, works of art necessarily bring into play specific ways of symbolizing which could be analyzed without any attempt to state on their aesthetic value. Likewise, we have adopted a non-normative approach to art and resorted to the analysis of languages used by artists to create new "symbolic worlds."

\section{Research settings}

Our research is based on the in-depth longitudinal study of Hamadryade, a firm which was operating in garden art and design during the study period (20042008). It is important to note that the case studied does not aim at "proving" or "validating" our theoretical statements, but at grounding them in empirical data, hence furthering the discussion with new insights. The criteria for selecting the case were thus more relative to their potential of discovery than of validation.

Regarding the history of Hamadryade, the project was originally launched in 1996 by Eliane, artist-gardener, and her husband, Pierre, also garden designer and jazz musician. This sole proprietorship turned into a firm in early 2003, set up by five people, including Eliane, Pierre and Sylvia who had a senior expertise in business administration and was expected to take charge of the managerial work. One of the two co-authors of this paper was also part of the five founding partners. The last partner was a gardener who had worked with Eliane and Pierre during the initial phase and who received shares to account for his historical commitment to the project. 
Although many collective crises threatened the survival of Hamadryade, the firm managed to triple its sales between the end of 2002 and 2008 and was employing ten people at the end of the study period. As a sign of this success, the firm made the cover of a famous French managerial magazine and won two regional prizes for the originality of the project. A local TV also did a short program on Eliane, who succeeded in developing Hamadryade's "Show Garden" at the end of 2005. Since then the firm has organized several private events on "art and gardening" and Eliane has also been collaborating with different artists, such as metal sculptors, for other regional shows. At the end of the study period, she participated in Saint-Jean de Beauregard Exhibition, one of the most famous garden exhibitions in France. Most of the clients of Hamadryade were private clients and the size of the projects ranged from small city gardens to bigger institutional parks and gardens. Figure 1 gives an illustration of Hamadryade's creations.

Figure 1 - An example of Hamadryade creations

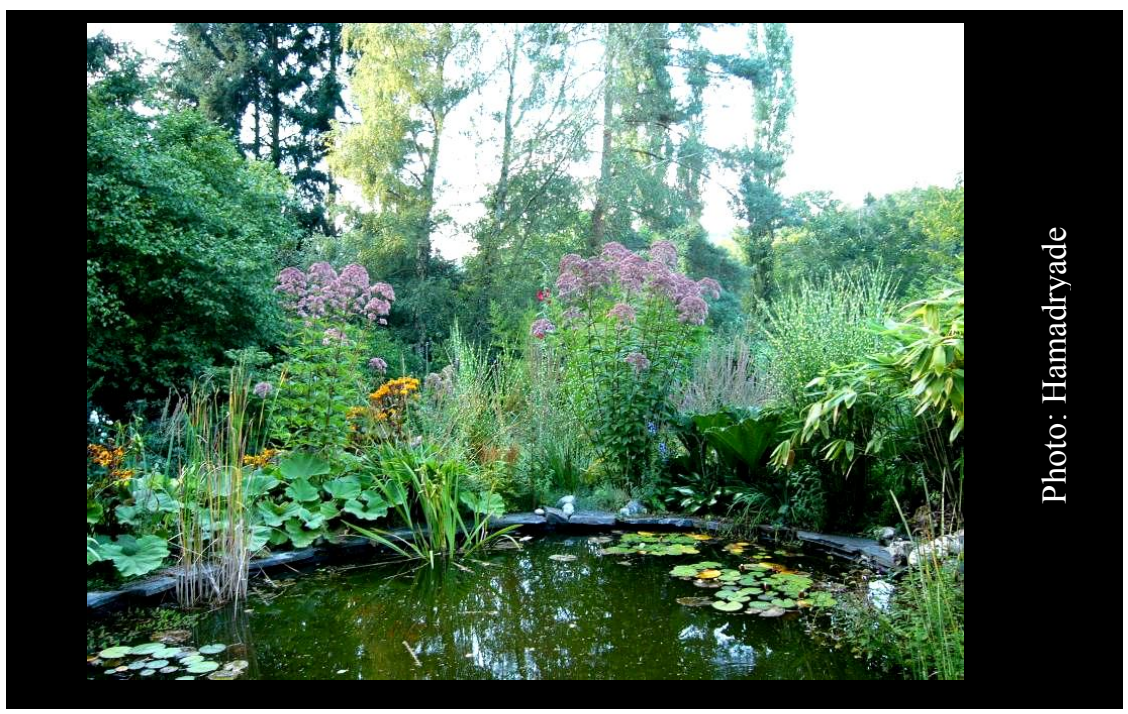

\section{Case study: unraveling the artist's symbolic activity}

In this section, we provide three main findings which tend to illustrate the limits of the pragmatic credo when facing the symbolic logic of artistic creation. Firstly, we show, through the example of the plants inventory, how a pragmatic approach to risk management ignores the necessity to organize "symbolic capabilities" for an artist. Secondly, we illustrate the limits of considering clients only as "market shares to be serviced" without regard for their interactions with the artistic development. Thirdly, discussing a traditional approach to operations 
management, we present findings about a strange logic of artistic creation which lies in the exploration, at work, of "signifying details", the source of which may not be known in advance.

\section{From "plants inventory" management to the organizing of a "vegetal palette"}

Observing that during the first months of the firm, Eliane had been persistently collecting a lot of plants which were not directly used, either for clients' gardens development, or for retail selling, but required maintenance and incurred costs, while facing climatic risks. Sylvia (the business manager) organized several meetings with the artist and argued in favor of radically lowering the inventory level of plants. Given the economic situation, this appeared reasonable. Nonetheless, Eliane was did not accept this analysis. She claimed that she needed a personal collection of plants to make her gardens and declared that it was at any rate "impossible to select the right plants on a catalogue." Although Eliane and Sylvia managed to retain a fragile compromise for a couple of months, this became the focal point of so many tensions within the organization that it eventually led to Sylvia's departure.

The firm then took this issue seriously into account and determined that it would organize a collaborative work based upon the on the "design languages." During the work sessions, Eliane was asked to "speak" of the garden to understand further what the "object to manage" was. This first phase was arduous because she could not avoid speaking "botanically" and it was difficult to reconstitute the entire genealogy of an "artistic garden." Still, the co-exploration went further and reveals that Eliane was not only "stocking" plants but was judiciously selecting "colors", "textures", "volumes", "odors" and even "sounds" to create and evoke original atmospheres. The collaborative work thus made it clear that management could not only consider plants as "commodities to be stored", but also as artistic materials required to complete the design work. Eliane thus considered necessary to possess not only the "managerially reasonable inventory level", but a huge variety of plants with which to compose her product. In that sense, she needed the organization of "symbolic capabilities" to explore new aesthetic effects. This analysis transformed the way the firm was considering the stock of plants and led to model the inventory as a "Vegetal Palette" crucial to Eliane in making her design (see Figure 2). Going beyond a pragmatic "costs/risks" perspective, the collaborative work on design languages thus led to a new and shared language of value which made it possible to discuss further the links between the sales and creative processes. 
Figure 2 - Organizing a "Vegetal Palette" for the artist

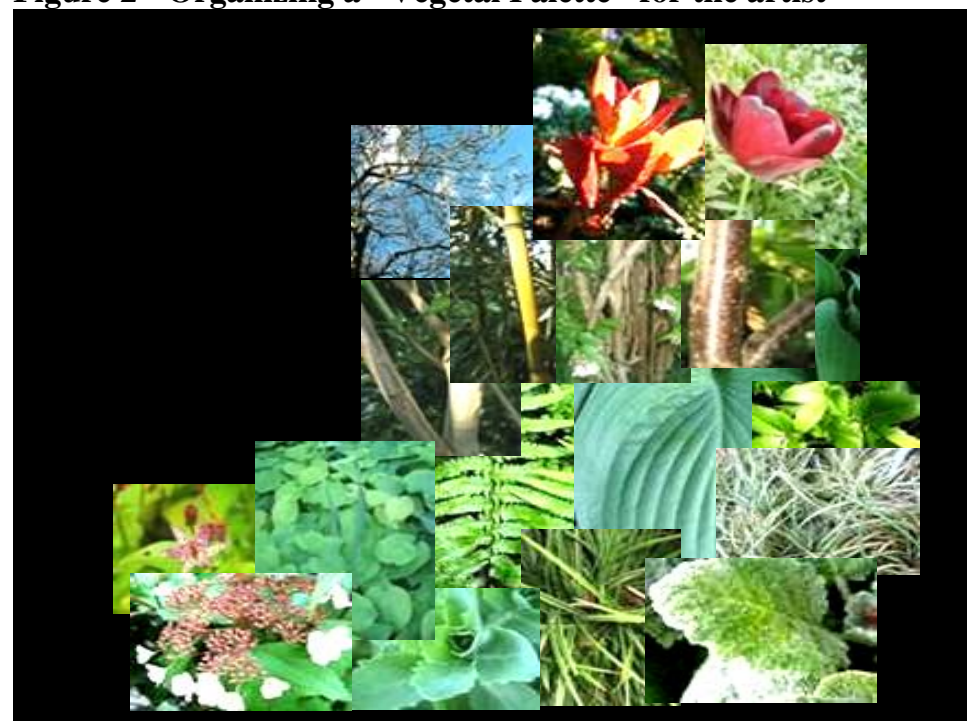

\section{From "client relation management" to the training to garden artistic experience}

If the creation process had been clarified thanks to the collaborative work on design languages, the question of the "reception" of gardens was still an unchartered territory. Until that moment, Sylvia had been using classic marketing tools, such as "market studies", to assess the needs of Hamadryade's clients and the way to increase the firm's market share. Still, while Eliane acknowledged the necessity to involve clients in their garden projects, she was uncomfortable with the idea of "asking" them their desires as such. She argued that most of the time, clients came with no idea of what could be a "true" garden or, even worse, with so many preconceptions about its nature that it was then almost impossible to explore new aesthetic effects. To her, this was a problematic situation which could not be solved only by "listening" to clients but requires something else to "make them see more than a bunch of roses and green plants." In addition, she disagreed with "working with any clients who may pay for it" and argued further that some clients, who were totally insensitive to garden art, could be dangerous for her as well as for the firm. Conversely, the artist's position led to the abandonment of several cash paying clients' projects and was, in that monetary sense, threatening the economic development of the firm.

Having made the design dimensions of Eliane's artwork visible was a new opportunity for the firm to appraise the client relations further. Indeed, if the plants inventory was not only an "inventory" but a space used as a "vegetal palette" to increase Eliane's "symbolic capabilities", it should therefore, neither be considered as an unproductive "retail store", nor as a costly "warehouse", but 
rather as a valuable "exhibition and learning space." In this space, the clients would be educated to the minimum "do-re-mi" of artistic gardening so that they could grasp the meaning of "the notes of the melodies to be played", i.e.: the plants in their volume, texture, color, or smell singularities. The firm therefore decided to open the doors of the vegetal palette, which turned into a micro "tree nursery collection" in which clients would not only have the possibility to buy plants but also be invited to enroll in training sessions. In particular, the visit of the vegetal palette was integrated to any garden design project in order to be sure that clients would have the minimal knowledge to perceive and feel the value of created gardens.

\section{From "operations management" to the acknowledging of artistic "signifying details"}

The collaborative work also made it possible to identify an original artistic logic of "signifying details." Indeed, after the establishment of the firm, many conflicts arose between Eliane and the other stakeholders around the notion of "detail." The latter considered that the real artistic work lay in the drawing of the "plantation plan" which was supposed to put an end to the whole garden design process and had therefore to be precisely and correctly implemented in practice. Variations which might occur during the planting phase had only to be "unsignifying" details that were supposed to be controlled thanks to an effective operations management. In contrast, Eliane believed that these details could precisely be "signifying details" which might turn out to be crucial to accomplish the artwork. For example, while the managers were expecting the plantation plan to be "precise", Eliane kept maintained that it was "impossible to detail a garden precisely on a leaf of paper." During the plantating phase, she was thus used to making "last minute" changes with few "explanations", which rendered these slight variations often incomprehensible to the executioners. The latter often even complained about her apparently "disorganized and imprecise process."

By disentangling the design languages, the collaborative work made it possible to restore a design process that consisted not only in the "geometrification" of a place ending with a "plan" (as deliverable), but that was, to a larger extent, linked to the actual task of making of the garden, which led to its "scenography", "texturalization", "sonorification", etc. In the case of Hamadryade, this led to further discuss the traditional distinction between design and execution, and to reassess the role of planting process in Eliane's artistic work. This reveals that, to her, "planting" did not only consist in putting plants according to a "plan", but also in fine "place-making" at work, in which any variation could play a role in and was vital to the whole scenography. These were understood to be "signifying details" as such. As another result of the collaborative work, the firm subsequently developed new types of design deliverables, such as "texture boards", in order to make the artistic work visible to clients in the early design phases. 


\section{Discussion: revisiting three pragmatist assumptions - dialogue, common world, effects of action}

In this section we develop our case study to suggest revisiting three basic pragmatist assumptions. First, we argue that "dialogue" is a false universal of action which reveals its limitations when organizing the co-presence of two symbolic orders. Secondly, we claim that artists' symbolic worlds differ from pragmatist "communities" in the sense that they do not suppose a "common world" which could be "understood" by anyone. Thirdly, we suggest that managers of art-based firms have to sustain specific symbolic processes, named "densification processes."

\section{Revising the "dialogic" assumption: from "dialogue" to the organizing of "co-presence"}

Whereas it is commonly assumed in the pragmatic credo that "dialogue" is a necessary and often sufficient prerequisite to organize collective action our findings suggest that a "dialogic model" albeit necessary is insufficient in the case of exploratory situations. Of course, one may consider that the conflictual relationship between Eliane and Sylvia was a "debate" about an unambiguous point (i.e.: the management of the plants inventory), which was eventually "solved" thanks to more "open-mindedness." In this perspective, our findings would only exemplify another case of "power negotiation" or search for "compromise", for the success of which a full-understanding of each other is often needed. Nevertheless, without being contradictory with such a view of power relationships, our case might exemplify something else. It seems that "dialogue" consists in reality in a false universal of action, the conditions of existence of which are not given in advance but have to be collectively explored and elaborated in practice. Of course, our argument is not "against" dialogue in general, but rather aims at clarifying that, regarded as a specific form of collective action, dialogue imposes a too "symmetrical relation" which ignores the logics of "co-presence" and normative differences. These logics are however absolutely necessary for discovering the "symbolic order" of the other (i.e. his values, beliefs, conventions, etc). Otherwise, how could one "observe" or "understand" one's symbolic order if the social form which organizes the relation to him/her precisely masks his/her symbolic order? In our case, a "full understanding" of each other was, to a certain extent, not the crucial objective and there was, to a larger extent, a need for comprehending the process of "co-expansion" of both the artist and manager. This is well illustrated by the collaborative work on the design languages which made it possible to establish a common language of value. 


\section{Revising the "common world" assumption: building a path to the artist's symbolic world}

It is traditionally admitted that the "market's voice" is a clumsy instrument and way of knowing the "real" value of goods. From a general pragmatist point of view, this refers to the idea of "truth is what works." More precisely, the managerial assumption, which states that for any products or services should correspond a distinct "market segment", is very close to the pragmatist reference to the notion of "community." According to the pragmatist philosophy, the notion of "community" designates a coherent group of people sharing the same "beliefs" and "habits of action" and living in a "common world." According to the managerial doctrine, it is linked to the consideration of a coherent group of customers sharing the same values and routines of consumption on a market. Our findings call attention to contrasting situations in which these "communities" does not necessarily exist as such. In these situations, how could firms "listen" to their clients, since the latter do not automatically possess the minimum knowledge to evaluate products or services? For instance, the way Hamadryade manages its "Vegetal Palette" illustrates an important effort to educate clients without any previous experience to artistic gardens. Such management differs from that of enquiry through classic "focus groups" in which customers are expected to prescribe the value of goods. Without being contradictory with approaches that put emphasis on the role of client "prescription" in product development, our findings suggest that the role of the firm is rather to organize "access" or build a "path" for potential clients to the artist's symbolic world. Such client relation management is certainly not always successful, as clients may follow a logic of, either "appropriation", or "rejection" of the artist's symbolic world. Nevertheless, this indicates that a pragmatic approach to market response seems insufficient in the case of art-based firms, especially because, unlike traditional firms, artists do not systematically attempt to be accepted by an existing "community" - of customers here -, but conversely intend to make people commit to their own symbolic order. This might indicate why artists are more likely to sustain "avant-garde" projects which, according to us, differ from "community" in the sense that they do not assume a "common world" in which anyone could find a place thanks to democracy or moral education.

\section{Revising the "effects of action" assumption: sustaining symbolic processes of "densification"}

It is widely accepted that managing efficiently consists in finding the right balance between "allocated resources" and "value perceived." From a pragmatist point of view, this assumption is linked to the idea of evaluating the "effects" of an action to determine the real "relevance" of this action. We all have in mind the pragmatist maxim enounced by Peirce as follows: "Consider what effects, that might conceivably have practical bearings, we conceive the object of our conception to have. Then, our conception of these effects is the whole of our 
conception of the object" (Peirce 1958). Still, our case reveals that Eliane, far from developing a practical prototype, nor conceiving of the possibility infinite iteration, absolutely refused to "consider all the effects of her action" in advance and that the symbolic development of her artistic work was rather coming from unknown "signifying details" to be discovered at work. This challenges the previous pragmatist assumption, for it does not assume a fixed symbolic "order of action" - defined as the way action is itself pre-categorized by a special class of symbols - which could determine, before creating, what a "signifying detail" could be. In addition, when making her gardens, Eliane authorizes herself to generate new details which have the potential for revising the whole initial - and even future - space of her artistic action. In reference to Nelson Goodman works on "languages of art" (Goodman 1968) and "ways of worldmaking" (Goodman 1978), Béjean suggested the notion of "densification" to account for such symbolic processes (Béjean 2008 2015). In Goodman's terms, the notion of "density" accounts for the level of responsiveness of a symbolic system toward "the finest differences in certain respects" (Goodman 1978, p.67-68) (i.e. what we have called "details" here). The level of density is determined by the way syntax and semantic are more or less structured and put in relation with a "referential domain." The notion of "densification" accounts for the process of expansion (Hatchuel and Weil 2003, 2009) of new "signifying details" in practice. In our view, this indicates that the role of an art-based firm manager may be to make these expansions possible and visible to clients and other stakeholders. Focusing on symbolic processes, such forms of managerial action seems not to resort to the pragmatic credo.

\section{Conclusion: beyond pragmatism, the need for an "epistemology of action"}

In this conclusive section we come back to the general discussion and address new questions to pragmatism to open a more general debate about action theory.

\section{Management learning from the arts: the necessary revision of the "orders of action"}

For management, the artistic contexts seem clearly to be an extreme case to deal with. Art actually puts managers in front of "unknown" situations which impose to revise the symbolic "orders of action." In the studied case, such difficulties have been well illustrated by different examples. For instance, whereas the other stakeholders were considering "planting" as a kind of "universal of action" in the art of gardening, it appears to be, from the point of view of the artist, the locus of signifying revisions. Planting a flowering shrub does not only consist in putting it in a sufficiently specified location thanks to a precise plantation plan which could totalize the dimensions of the artistic intention. It also consists in unfolding new "signifying details" during the plantation process along with new design dimensions (textures, odors, colors, light effects...). We do not argue that 
any plantation tends or makes it possible to create such artistic effects, but rather suggest that some plantations may be "denser" than others. The rate of densification should thus be considered not as an "effect" of plantation but as a new theory of the action of planting which includes the "revision" of the gardener artistic subjectivity itself (e.g.: new space of artistic action, new values, beliefs...). The fact that, overlooking "densification", traditional pragmatic approaches consider symbolic activity only as "clarification" or "precision" may explain their difficulties to deal with art-related contexts. Facing the unknown, they illusionary believe that it would be sufficient to "act", "experiment" or "learn by doing." Still, while our findings already emphasize the dangers of such pragmatic approach, at least in the case of collective action in artistic contexts, we will now briefly remind how modern science has precisely been a criticism of implicit "orders of action."

\section{A brief "detour": modern science as a criticism of implicit "orders of action"}

As previously analyzed by Hatchuel (2005), there are a lot of examples in which modern science had to revise its implicit theories of action. Let's take the apparently simple question unfolded by Mandelbrot in Science in 1967: "How long is the coast of Britain?" What would have answered a pragmatist author such as Peirce to that question? Probably that, once established a consensus on the relevant scale, degree of precision and means of measurement, the correct "length" of the coast of Britain will be the result, and no more than this "result" or "effect", of our action of measurement (potential or real). Still, Mandelbrot discovered some strange "effects" of the action of measuring which make the "length" of the coast of Britain increase with the type of scale selected. This would have already been a serious problem for pragmatists who do not consider truth as "mutable" (see section 1). In addition, the increase of the length was not only a "convention" to specify, but could be a new and general indicator to "measure" a space. While extending the traditional notion of "dimension", this indicator could even be scientifically formalized and calculated. This was thus absolutely not a unique question of "clarification" or "precision" (Peirce 1878), which could have been solved thanks to a pragmatist "community of inquiry" (Dewey 1938), but consisted in a deep revision of the implicit symbolic order of the action of "measuring." As Hatchuel notes: "The critical point is that we can only measure (including by consensus) that which we have, ourselves, made measurable beforehand: for example, a calculable geometric shape. As for the rest, measuring is an act which is both conforming (may be self-fulfilling) and exploratory (discovers the 'real'). In other words, measuring creates as many realities as it uncovers or destroys. This remark also defines the epistemology of every quantitative indicator in the field of management, for example, all the measurements involved in accounting." (Hatchuel 2005, p. 42) Similarly, in the case of artistic gardening, we discover through this illustrative example how 
facing the "unknown" requires us to revise implicit "orders of action." It demonstrates the way in which a co-expansive interaction between "action" and "effects" which seems to go beyond the traditional pragmatist view of experimentation. As for the history, Mandelbrot's discovery was also the starting point of fractal geometry.

\section{From the "pragmatic credo" to an "epistemology of action"}

If we now come back to the pragmatic credo, we can conclude that, albeit apparently wise and reasonable, it implicitly assumes a pre-established symbolic "order of action" which is also supposed appropriate and performative. Still, this often leads to circular formulations that we find for example in standard economics such as: "there are 'market laws' because markets self-regulate and markets self-regulate because people act pragmatically according to 'market laws'..." Likewise, if resorting to "action" in order to establish common truth, ethics and society could appear attractive, we have provided examples which illustrate that it may also mask particular situations in which "action" is precisely the "enigma" to be unfolded and not the "solution" to resort to. In such situations, we have argued (Starkey et. al. 2009; Hatchuel et al. 2010) that a specific form of collective endeavor (and management) is needed to revise the implicit models of (collective) action and to generate new cognitive symbols and new types of social relations. Studying the conditions and processes of how "orders of action" are revised is the task of an "epistemology of action" which necessarily encompasses pragmatism; the latter appearing now only as a too restrictive and limited theory of action. In particular, we have tried to demonstrate that artists seem to offer models which unveil the central place of the symbolic "orders of action" as well as their necessary regeneration. As with Scientific knowledge, they help us to expand our traditional view of action. Finally, this is also consistent with what history tells us about the impact of Art and Science in modern and postmodern societies: they not only create forms and knowledge, but may also completely change how we think about collective action.

\section{References}

Barry, D. and H. Hansen, Eds. 2008). The SAGE Handbook of New Approaches in Management and Organization. London: Sage Publications.

Béjean, M. 2008. Le management des entreprises à prestations artistiques: activités de conception, régimes de signification et potentiel de croissance. CGS-Mines ParisTech. PhD.

Béjean, M. 2015. Le management à l'épreuve des activités de création: enquête sur les régimes de signification dans les entreprises de création contemporaines. Sarrebruck: Editions universitaires européennes.

Bilton, C. 2006. Management and Creativity: From Creative Industries to Creative Management. Oxford: Blackwell Publishing. 
Dewey, J. 1916. Democracy and Education : an Introduction to the Philosophy of Education. New York: The Macmillan Company.

Dewey, J. 1938. Logic: The Theory of Inquiry. New York: Henry Holt and Co.

Dewey, J. 1969-1975. The Early Works, 1882-1898. Carbondale, IL: Southern Illinois University Press.

Fayol, H. 1916. Administration Industrielle et Générale. Bulletin de la Société de l'Industrie Minérale (No. 10).

Goodman, N. 1968. Languages of art. Indianapolis: Hackett Publishing Company.

Goodman, N. 1978. Ways of worldmaking. Indianapolis: Hackett Publishing Company.

Guillet de Monthoux, P. 2004. The Art Firm - Aesthetic Management and Metaphysical Marketing. Stanford, California: Stanford University Press.

Gulick, L. H. 1937. Notes on the theory of organization. In Papers on the Science of Administration, ed L. H. Gulick and L. F. Urwick, 1-46. New York: Colombia University Press.

Gulick, L. H. and L. F. Urwick, Eds. 1937. Papers on the Science of Administration. New York: Colombia University Press.

Haack, S. 1995. Vulgar Pragmatism: An Unedifying Prospect. In Rorty \& Pragmatism: The Philosopher Responds to His Critics, ed H. J. Saatkamp, 126153. Nashville: Vanderbilt University Press.

Hatchuel, A. 2005. Towards an epistemology of collective action: management research as a responsive and actionable discipline. European Management Review 2(1): 36-47.

Hatchuel, A. and B. Weil. 2003. A new approach of innovative design: an introduction to $C / K$ theory. ICED 2003, Stockholm.

Hatchuel, A. and B. Weil. 2009. C-K theory: an advanced formulation. Research in Engineering design 19: 181.

Hatchuel, A., Starkey K., Tempest S. and P. Le Masson. 2010. Strategy as innovative design: An emerging perspective. In The Globalization of Strategy Research (Advances in Strategic Management Vol. 27), ed Baum Joel A.C. and Joseph Lampel, 3-28. Bingley, UK: Emerald Group Publishing Limited.

Hirsch, P. 2000. Cultural industries revisited. Organization Science 11(3): 356361.

Joas, H. 1996. The Creativity of Action. Chicago, IL: University of Chicago Press.

Lovejoy, A. O. 1908. The Thirteen Pragmatisms. II. The Journal of Philosophy, Psychology and Scientific Methods 5(2): 29-39.

Peirce, C. S. 1878. How to make our Ideas Clear. In Writings of Charles $S$ Peirce. Indianapolis: Indiana University Press.

Peirce, C. S. 1958. Collected Papers of Charles Sanders Peirce. Cambridge, MA: Harvard University Press.

Putnam, H. 1981. Reason, Truth, and History. Cambridge: Cambridge University Press. 
Putnam, H. 2004. The Collapse of the Fact/Value Dichotomy: And Other Essays. Cambridge: Massachusetts, Harvard University Press.

Rorty, R. 1991. Objectivity, Relativism and Truth: Philosophical Papers I. Cambridge: Cambridge University Press.

Sicca, L. M. 2000. Chamber Music and Organization Theory: Some Typical Organizational Phenomena Seen under the Microscope. Studies in Cultures Organizations and Societies 6(2): 145-168.

Riot, E, and Y Bazin. 2013. Imperceptible or Insensible? The Aesthetics of Gestures, Choices and Moves at Work. Society and Business Review 8(3): 1-1.

Starkey, K. Armand Hatchuel, Sue Tempest. 2009. Management Research and the New Logics of Discovery and Engagement. Journal of Management Studies 46(3): 547-558.

Strati, Antonio. 1992. Aesthetic Understanding of Organizational Life. American Management Review 17(3): 568-581.

Taylor, S. S. and H. Hansen. 2005. Finding Form: Looking at the Field of Organizational Aesthetics. Journal of Management Studies 42(6): 1211-1231.

William, J. 1912. Essays in radical empiricism. New York: Longmans.

Yin, R. K. 2003. Case Study research: design and method (3d Ed). Thousand Oaks, CA: Sage publication.

\section{Biography}

Mathias Béjean is Associate Professor at Université Paris Est Créteil and member of the Institut de Recherche en Gestion (EA 2354). His research focuses on innovation management, meaning-making and design processes. In collaboration with Andrée Ehresmann, mathematician, he is developing a theoretical approach named D-MES which aims to unify the internal and external dynamics of collective processes of creation and anticipation. He has published several articles in academic journals and international conferences. He also teaches innovation by design at ENSCI Paris Design Institute.

Armand Hatchuel is currently full Professor at Mines ParisTech / PSL Research University and co-head of the "Design theory and methods for innovation » Chair. He pioneered research on the cognitive dynamics and the "epistemology of collective action", exploring new foundations for Management studies and for the notion of "expandable rationality" that helps to co-construct imagination and critical reason. He formalized these ideas in a theory of creative thinking and design called "C-K theory" (Concept-Knowledge theory) that received wide interest in several disciplines (Engineering, psychology, Management, industrial design, philosophy...). He has published extensively in academic journals and co-authored several books. He has been awarded as Fellow of the Design Society and member of the French Academy of Technologies. 